\title{
Total Phenol Content and Antioxidant Activity of Different Celta Pig Carcass Locations as Affected by the Finishing Diet (Chestnuts or Commercial Feed)
}

\author{
Noemí Echegaray ${ }^{1}{ }^{(D}$, Paulo E. S. Munekata ${ }^{1}$, Juan A. Centeno ${ }^{2}$, Rubén Domínguez ${ }^{1}{ }^{\circledR}$, Mirian Pateiro ${ }^{1}(\mathbb{D}$, \\ Javier Carballo $^{2} \mathbb{D}$ and José $M$. Lorenzo ${ }^{1,2, * \mathbb{D}}$ \\ 1 Centro Tecnológico de la Carne de Galicia, Rúa Galicia No 4, Parque Tecnológico de Galicia, San Cibrao das \\ Viñas, 32900 Ourense, Spain; noemiechegaray@ceteca.net (N.E.); paulosichetti@ceteca.net (P.E.S.M.); \\ rubendominguez@ceteca.net (R.D.); mirianpateiro@ceteca.net (M.P.) \\ 2 Área de Tecnología de los Alimentos, Facultad de Ciencias de Ourense, Universidad de Vigo, \\ 32004 Ourense, Spain; jcenteno@uvigo.es (J.A.C.); carbatec@uvigo.es (J.C.) \\ * Correspondence: jmlorenzo@ceteca.net; Tel.: +34-988-548-277; Fax: +34-988-548-276
}

check for updates

Citation: Echegaray, N.; Munekata, P.E.S.; Centeno, J.A.; Domínguez, R.; Pateiro, M.; Carballo, J.; Lorenzo, J.M. Total Phenol Content and Antioxidant Activity of Different Celta Pig Carcass Locations as Affected by the Finishing Diet (Chestnuts or Commercial Feed). Antioxidants 2021, 10, 5. https://dx.doi.org/10.3390/ antiox10010005

Received: 17 November 2020 Accepted: 21 December 2020 Published: 23 December 2020

Publisher's Note: MDPI stays neutral with regard to jurisdictional claims in published maps and institutional affiliations.

Copyright: () 2020 by the authors. Licensee MDPI, Basel, Switzerland. This article is an open access article distributed under the terms and conditions of the Creative Commons Attribution (CC BY) license (https: / / creativecommons.org/ licenses/by/4.0/).

\begin{abstract}
The objective of this research was to evaluate the total phenol content, total flavonoids, and antioxidant activity of chestnuts (Castanea sativa Mill.) and commercial feed employed in the finishing diet of the Celta pig breed and analyze the effect of the feeding (chestnuts vs. commercial feed) in the finishing diet on total phenol content and antioxidant activity of Longissimus thoracis et lumborum, Psoas major, and Biceps femoris muscles and liver of the Celta pig breed. The antioxidant activity of the feed and animal tissue was investigated using three antioxidant methods (2,2-Diphenyl-1-picrylhydrazyl (DPPH) radical scavenging activity, 2-2'-Azino-di-[3-ethylbenzthiazoline sulfonate] (ABTS) radical scavenging activity, and ferric reducing antioxidant power (FRAP) assay). The determination of the total phenol content and total flavonoids showed that chestnut had a significantly lower concentration than commercial feed in these compounds (130.00 vs. $312.89 \mathrm{mg}$ gallic acid equivalents $/ 100 \mathrm{~g}$ fresh weight and 8.58 vs. $32.18 \mathrm{mg}$ catechin equivalents $/ 100 \mathrm{~g}$ fresh weight, respectively). However, the results displayed that chestnuts had a higher antioxidant activity when compared with the commercial feed through the DPPH and ABTS methods (1152.42 vs. $957.33 \mu \mathrm{g}$ Trolox equivalents/g fresh weight, and 9379.74 vs. $7613.44 \mu \mathrm{g}$ Trolox equivalents/g fresh weight, for DPPH and ABTS assay, respectively), while the antioxidant activity measured by the FRAP assay turned out to show higher values for commercial feed (1777.49 and $1946.09 \mu \mathrm{mol} \mathrm{Fe}{ }^{2+} / 100$ fresh weight for chestnut and commercial feed, respectively), although significant differences were only found in the ABTS assay. On the other hand, the present study found that chestnut significantly reduces the total phenol content and declines the antioxidant activity of Longissimus thoracis et lumborum, Psoas major, and Biceps femoris muscles and liver of the Celta pig breed. Finally, it has been found that liver is the location that has the best antioxidant characteristics compared to any muscle, regardless of diet utilized.
\end{abstract}

Keywords: Celta pig breed; animal diet; chestnut; commercial feed; muscle tissue; liver; total phenol content (TPC); total flavonoids; antioxidant activity

\section{Introduction}

During the shelf life and storage of food, oxidative processes generate the degradation of pigments, lipids, and proteins that simultaneously can contribute to the deterioration of color, texture, taste, and nutritional value of the nourishments [1-3]. This is the case for fresh meat, which, due to its chemical characteristics, is prone to oxidative deterioration [4-6]. For their part, antioxidants are chemical compounds capable of donating hydrogen to the free radicals, which can prolong the shelf life of meat, delaying the oxidation of lipids, loss of color, and microbial growth [7]. Therefore, with the purpose of minimizing the decline 
process in meat and meat products, the use of additives with antioxidant properties has been widely used in meat processing [8-11]. Specifically, the current trend in the meat industry is the use of natural antioxidants to the detriment of synthetics compounds on account of their toxic potential [12]. In this regard, vegetal resources are a rich origin of polyphenolic compounds, which are secondary metabolites of plants with antioxidant properties [13,14]. This is the case of the chestnut (Castanea sativa. Miller) fruit, because this kernel is an important source of phenol compounds such as phenolic acids (chlorogenic, coumaric, ellagic, ferulic, and gallic acid), flavonoids (apigenin, rutin, and quercetin), and tannins [15-18].

On the other hand, the population is currently also highly interested in the consumption of meat and meat products obtained from ancient autochthonous genetic types. These occurrences respond to the fact that the breeding and management of autochthonous breeds is conditioned to animal welfare, considering that the livestock raised in this way have the ability to express the natural behavior of the species, at the same time that the high quality and qualitative and organoleptic characteristics of meat thrive [19,20]. On this matter, the Celta pig breed originally from Galicia (northwest Spain) takes on special interest, since these pigs have traditionally been reared in extensive or semi-extensive systems employing natural food sources such as chestnut. In this sense, the products obtained from pigs fed chestnuts are characterized by their high quality in terms of the intense fat infiltration into lean, their healthier fat, and their succulent meat [21,22]. More concretely, the use of chestnuts has been shown to increase the degree of unsaturation of fat in meat and meat products [21,23-25]. This characteristic, although it is beneficial for health, could have a detrimental effect on meat, because unsaturated fatty acids are easily susceptible to oxidation [3]. Nevertheless, this situation has not been displayed in preliminary studies [24,26-28]. In this way, Cobos et al. [27] observed that the inclusion of $15 \%$ chestnut flour in a pig diet decreased the lipid oxidation of a dry-cured pork foreleg. Similarly, Pugliese et al. [24] demonstrated that the use of chestnuts during the last three months of pig feeding prevented the risk of lipid oxidation, since they found low values of malonaldehyde (MDA) in meat from pigs fed with this fruit. Furthermore, a previous trial of our research group conducted on cooked meat found that the inclusion of chestnut in the finishing diet of the Celta pig exerted a protective effect on lipids of the Longissimus thoracis et lumborum muscle [28]. Additionally, other studies showed that the use of chestnuts in pig fattening did not modify lipid oxidation in both fresh meat and its derivatives [29-31].

These effects could be due to the phenolic compounds of the chestnut fruit, which once ingested by the pig could be accumulated in the animal tissues and exert a protective effect on the meat lipids, ameliorating the shelf life and the technological quality of meat $[20,32,33]$. Notwithstanding, despite these findings, the information on the relationship between the antioxidant characteristics of the diet containing chestnuts and the total phenol content as well as the antioxidant capacity of pig tissues is nonexistent. Therefore, the purpose of the present study was to analyze the total phenol content, total flavonoids, and antioxidant activity of chestnuts (Castanea sativa Mill.) and commercial feed used in the finishing diet of Celta pig breed, as well as to investigate the effect of the feeding (chestnuts or commercial feed) in the finishing diet on total phenol content and antioxidant activity in diverse locations in the carcass (Longissimus thoracis et lumborum, Psoas major, and Biceps femoris muscles, and liver).

\section{Materials and Methods}

\subsection{Experiment Design and Pig Slaughter}

A total of 18 Celta pigs (10 males and 8 females) raised in a semi-extensive system were employed for this work. The piglets were weaned until 40 days and were vaccinated and deparasitized according to the standard protocols. After suckling, the pigs were reared in a semi-extensive regime with a livestock density of 12 animals per hectare and fattened with a commercial compound. Males and females were castrated under anesthesia and additional prolonged analgesia at the age of 2 and 3 months, respectively, in accordance 
with the Council Directive 2008/120/EC [34]. The pigs were randomly split into 2 distinct groups of 9 animals ( 5 males and 4 females) at the age of 8 months for their special feeding during the finishing period (4 months). The animals were maintained in distinct portions of land, guaranteeing that there was not any other vegetation which pigs had access to. One of the groups, after eating a transition mixed diet composed of commercial compound feed and chestnuts ( $1.5 \mathrm{~kg}$ and $3 \mathrm{~kg}$ per animal and day, respectively) during the ninth month, were fed with $6 \mathrm{~kg}$ of chestnuts per animal and day in the remaining three months previously to slaughter. The pigs of the other group were fattened with $3 \mathrm{~kg}$ of commercial feed per animal and day during the 4 months prior to the slaughter age.

At the end of the fattening period, livestock was transported $80 \mathrm{~km}$ to a commercial abattoir (Frigolouro, Porriño, Pontevedra, Spain) and were kept for $12 \mathrm{~h}$ with free access to water but not to nourishment. Animals were slaughtered with a mean live weight of $107.53 \pm 8.26 \mathrm{~kg}$ for pigs fed with chestnut and $115.41 \pm 9.15 \mathrm{~kg}$ for pigs fed with commercial feed $(P>0.05)$. The slaughtering method was carried out by electrical stunning and exsanguination. Subsequently, pigs were scalded, skinned, and eviscerated following standard commercial procedures. Straight away, carcasses were chilled at $4 \pm 1{ }^{\circ} \mathrm{C}$ in a cold chamber for $24 \mathrm{~h}$. After the cooling period, samples from Longissimus thoracis et lumborum, Psoas major, and Biceps femoris muscles and from the liver from each carcass were extracted and preserved chopped in vacuum-sealed bags at $-80 \pm 2{ }^{\circ} \mathrm{C}$ until processing.

\subsection{Finishing Diet Material}

Chestnut samples were obtained from a mix of the Spanish cultivars Amarelante, Famosa, Longal, and Judía. The fruits were harvested between the months of October and November 2015 from orchards of different points in the provinces of Lugo, Ourense, and León (northwest Spain). After collection of samples, chestnuts were stored in a refrigerator at $4 \pm 1{ }^{\circ} \mathrm{C}$ for a maximum of 3 days until they were hand-peeled, separating the tegument tissue. Continuously, the peeled fruit was chopped and stored in vacuum-sealed bags at $-80 \pm 2{ }^{\circ} \mathrm{C}$ until subsequent extraction.

Commercial pig feed composed of barley, roasted and decorticated soybean-extracted flour, maize, wheat, bran, winemaking lees and maize soluble, beet molasses, calcium carbonate, phosphate, mineral dicalcium, soybean hulls, vegetable palm oil, and sodium chloride and supplemented with trace minerals, vitamins, provitamins, and chemically defined substances, which have an effect analogous to Vitamins $A, D_{3}$, and E, were supplied by Sarriana de Piensos S.A. (Lugo, Spain). Composition of the commercial feed is shown in Table 1. Upon receipt, this commercial nourishment was chopped and stored in vacuumsealed bags at $-80 \pm 2{ }^{\circ} \mathrm{C}$ until processing.

The chemical, cholesterol, retinol, and fatty acid composition and the energy of the two different diets used in the finishing diet of Celta pigs (chestnuts and commercial feed) were reported in previous studies $[23,30]$.

Table 1. Composition of the commercial feed used in the feeding of pigs.

\begin{tabular}{cccc}
\hline Component & $\mathbf{( \% )}$ & Supplements & UI (Vitamins) or mg (Minerasls)/kg \\
\hline Crude & 16.01 & Vitamin A & 6500 \\
protein & & Vitamin D3 & 1500 \\
Crude fiber & 5.01 & Vitamin E & 15 \\
Crude fat & 2.98 & Manganese sulphate & 40 \\
Crude ashes & 5.83 & Zinc oxide & 60 \\
Lys & 0.72 & Iron sulphate & 50 \\
Met & 0.25 & Copper sulphate & 15 \\
Thr & 0.12 & Potassium iodide & 0.5 \\
Trp & 0.01 & Sodium selenite & 0.1 \\
Ca & 0.88 & & \\
P & 0.61 & & \\
Na & 0.17 & & \\
\hline
\end{tabular}




\subsection{Extract Preparations}

The extracts utilized to determine the phenolic compounds, flavonoids content (determined only in pig feed and not in meat samples), as well as the antioxidant assays were carried out following the method proposed by Santos et al. [35], with slight modifications. Succinctly, three grams of previously chopped and thawed sample were disrupted for $60 \mathrm{~s}$ using an IKA T25 digital Ultra-Turrax (IKA ${ }^{\circledR}$-Werke GmbH \& Co. KG, Staufen, Germany) in $20 \mathrm{~mL}$ of $\mathrm{CH}_{3} \mathrm{OH}: \mathrm{H}_{2} \mathrm{O}(80: 20, v / v)$. Then, homogenate was stirred at $50 \mathrm{rpm}$ on a rocking shaker (SW-3D-E, OVAN, Barcelona, Spain) for $15 \mathrm{~min}$, at room temperature. After stirring, samples were placed in an ultrasound water bath apparatus (Bransonic ${ }^{\circledR}$ $8510 \mathrm{E}-\mathrm{DTH}$, Danbury, CT, USA) for $15 \mathrm{~min}$ at $25^{\circ} \mathrm{C}$. Subsequently, they were centrifuged at $14,000 \times g$ and $4{ }^{\circ} \mathrm{C}$ during $15 \mathrm{~min}$, and supernatant was separated and filtered through $0.45 \mu \mathrm{m}$ pore filter (Acrodisc ${ }^{\circledR}$ LC PVDF syringe filter; Pall Gelman Laboratory, Montreal, QC, Canada). The methanolic extracts were stored protected from direct exposition to light at $-80{ }^{\circ} \mathrm{C}$ prior to their corresponding analysis.

\subsection{Determination of Total Phenol Content (TPC)}

Total phenol content was estimated following the Folin-Ciocalteu method for total phenolics, which is substantiated on the colorimetric oxidation/reduction reaction of phenols. This assay was carried out according to the method initially described by Singleton and Rossi [36], with some modifications. Basically, $500 \mu \mathrm{L}$ of methanolic sample extracts (diluted for convenience) were added to $2.5 \mathrm{~mL}$ of Folin-Ciocalteu: $\mathrm{H}_{2} \mathrm{O}$ reagent (1:10, $v / v)$ and mixed before adding $2.0 \mathrm{~mL}$ of $7.5 \%(w / v) \mathrm{NaCO}_{3}$. The mix was incubated in a water bath at $45{ }^{\circ} \mathrm{C}$ and absorbance at $765 \mathrm{~nm}$ was read employing a spectrophotometer UV-1800 (Shimatzu Corporation, Kyoto, Japan) after cooling at room temperature during $30 \mathrm{~min}$. Readings were compared with a standard curve of gallic acid (ranged from 0 to $100 \mathrm{mg}$ gallic acid/L), being the total phenol content expressed as milligrams of gallic acid equivalents (GAE) per $100 \mathrm{~g}$ of fresh weight (FW) of pig feed or pig tissue.

\subsection{Determination of Total Flavonoids}

Total flavonoids were determined in chestnut and commercial feed by the aluminum chloride colorimetric method initially described by Zhishen et al. [37], with slight changes proposed by Rodrigues et al. [38]. Firstly, $1 \mathrm{~mL}$ of the methanolic extract (diluted for convenience) was mixed with $4 \mathrm{~mL}$ of distilled water and $300 \mu \mathrm{L}$ of a $5 \%(w / v) \mathrm{NaNO}_{2}$ solution. After $5 \mathrm{~min}, 300 \mu \mathrm{L}$ of a $10 \%(w / v) \mathrm{AlCl}_{3}$ solution was mixed in, and $1 \mathrm{~min}$ later, $2 \mathrm{~mL}$ of $1 \mathrm{M} \mathrm{NaOH}$ and $2.4 \mathrm{~mL}$ of distilled water were also added. The solution was mixed in a vortex and the absorbance was read at $510 \mathrm{~nm}$ using a spectrophotometer UV1800 (Shimatzu Corporation, Kyoto, Japan). (+)-Catechin (ranged from 0.250-2.500 mM) was employed to calculate the standard curve and the results were expressed as $\mathrm{mg}$ of $(+)$-catechin equivalents (CAE) per $100 \mathrm{~g}$ of fresh weight $(\mathrm{FW})$ of pig feed or pig tissue.

\subsection{2,2-Diphenyl-1-Picrylhydrazyl (DPPH) Radical Scavenging Activity}

DPPH radical scavenging activity is a technique considered a standard for the in vitro evaluation of antioxidants, which is widely employed for the evaluation of free radical scavenging potentials of distinct compounds [39]. This method was accomplished based on the procedure described by Brand-Williams et al. [40], with some modifications. Briefly, $100 \mu \mathrm{L}$ of the methanolic sample extract (diluted for convenience) were incubated at $37^{\circ} \mathrm{C}$ for $10 \mathrm{~min}$ after adding $3900 \mu \mathrm{L}$ of a methanolic DPPH solution $(60 \mu \mathrm{M})$ prepared daily and mixed in a vortex. Absorbance was read at $515 \mathrm{~nm}$ in a spectrophotometer UV-1800 (Shimatzu Corporation, Kyoto, Japan). The DPPH radical scavenging activity of the samples was calculated from a standard curve of Trolox (ranged from 0 to $1.2 \mathrm{mM}$ Trolox) and expressed as $\mu \mathrm{g}$ Trolox equivalents (TE)/g fresh weight (FW) of pig feed or pig tissue. 


\subsection{2-2'-Azino-di-[3-Ethylbenzthiazoline Sulfonate] (ABTS) Radical Scavenging Activity}

ABTS discoloration assay of samples was determined following the adapted Troloxequivalent antioxidant capacity (TEAC) method firstly explained by Re et al. [41], with slight changes. This method is substantiated on the ability of antioxidants to quench the long-lived ABTS radical cation, a bluish-green chromophore with a specific absorption line at $734 \mathrm{~nm}$. The ABTS radical cation was produced by reacting $7.00 \mathrm{mM}$ ABTS stock solution with $2.45 \mathrm{mM}$ potassium persulfate, a strong antioxidant agent. The mixture was incubated in the dark at room temperature for 12-16 h before use. Previously to being utilized, the ABTS solution was diluted with distilled water to reach an absorbance of $0.700 \pm 0.020$ at $734 \mathrm{~nm}$, and equilibrated at $30^{\circ} \mathrm{C}$. Following, an aliquot of $20 \mu \mathrm{L}$ of methanolic extracts of the samples (diluted for convenience) was added to $980 \mu \mathrm{L}$ of the working ABTS solution and the absorbance was read at the specific wavelength $(734 \mathrm{~nm})$ utilizing a spectrophotometer UV-1800 (Shimatzu Corporation, Kyoto, Japan) after $10 \mathrm{~min}$ in darkness. A standard curve of Trolox (ranged 0-2.0 mM Trolox) was employed for the quantification of the ABTS radical scavenging activity and outcomes were expressed as $\mu \mathrm{g}$ Trolox equivalents (TE)/g fresh weight (FW) of pig feed or pig tissue.

\subsection{Ferric Reducing Antioxidant Power (FRAP) Assay}

The FRAP assay was carried out following the method previously described by Benzie and Strain [42], with brief changes. This method is based on the ability of certain antioxidants species to reduce iron (III) to the ferrous form (II) in acid medium, which develops a blue color. In this way, this test measures the development of an intense navy-blue color that corresponds to the formation of $\mathrm{Fe}^{2+}-2,4,6$-Tri(2-pyridyl)-1,3,5-triazine (TPTZ) complex from the colorless oxidized $\mathrm{Fe}^{3+}$-TPTZ complex, which has a maximum absorbance at $593 \mathrm{~nm}$. FRAP solution was freshly prepared by dissolving an acid solution of $10 \mathrm{mM}$ 2,4,6-tripyridyl-s-triazine (TPTZ) in $40 \mathrm{mM} \mathrm{HCl}$, an aqueous solution of $20 \mathrm{mM}$ $\mathrm{FeCl}_{3}: 6 \mathrm{H}_{2} \mathrm{O}$, and a buffer solution of $300 \mathrm{mM}$ acetate buffer $(\mathrm{pH} 3.6)$ at a ratio of 1:1:10 (v:v:v). Afterwards, to $900 \mu \mathrm{L}$ of FRAP reagent $90 \mu \mathrm{L}$ of distilled water and $30 \mu \mathrm{L}$ of the methanolic extracts (diluted for convenience) were added. This mixture was incubated for $20 \mathrm{~min}$ at $37^{\circ} \mathrm{C}$ in darkness and the absorbance was measured at $593 \mathrm{~nm}$ employing a spectrophotometer UV-1800 (Shimatzu Corporation, Kyoto, Japan) after cooling at room temperature for $15 \mathrm{~min}$. Ferrous sulphate solutions $\left(\mathrm{FeSO}_{4} \cdot 7 \mathrm{H}_{2} \mathrm{O}\right)$, ranging from $0-2 \mathrm{mmol}$, were utilized to obtain the calibration curve. The FRAP values were expressed as $\mu \mathrm{mol}$ $\mathrm{Fe}^{2+} / 100 \mathrm{~g}$ fresh weight of pig feed or pig tissue.

\subsection{Statistical Analysis}

In each feed and in each location of each pig carcass, determinations were made in triplicate for each parameter. With the purpose of analysis, the differences between chestnut and commercial feed, as well as the sway of feeding and muscle location in Celta pigs on the different parameters studied, an analysis of variance (ANOVA) using the General Linear Model (GLM) procedure of the SPSS package version 23.0 (IBM SPSS, Chicago, IL, USA) was accomplished. Following, Duncan's test was carried out. Correlations between variables were determined employing the Pearson's linear coefficient implemented with SPSS package, version 23.0. $P$ values were determined and levels of significance were expressed as $P<0.05, P<0.001$ or $P<0.001$.

\section{Results and Discussion}

\subsection{Total Phenol Content of Feed Used in the Finishing Diet of Celta Pigs}

Total phenol content (TPC) are mainly composed of phenolic acids, flavonoids, and anthocyanins. In the case of chestnut fruit, some of the most important phenolic substances found are gallic, chlorogenic, coumaric, ferulic and ellagic acids, and catechin, quercetin, and rutin [18], while in commercial feed it depends on the nature of grains and supplements used in its preparation. Figure 1 displays the results corresponding to the TPC of chestnut and commercial feed employed in the finishing diet of Celta pig as mg GAE/100 $\mathrm{g}$ FW. 


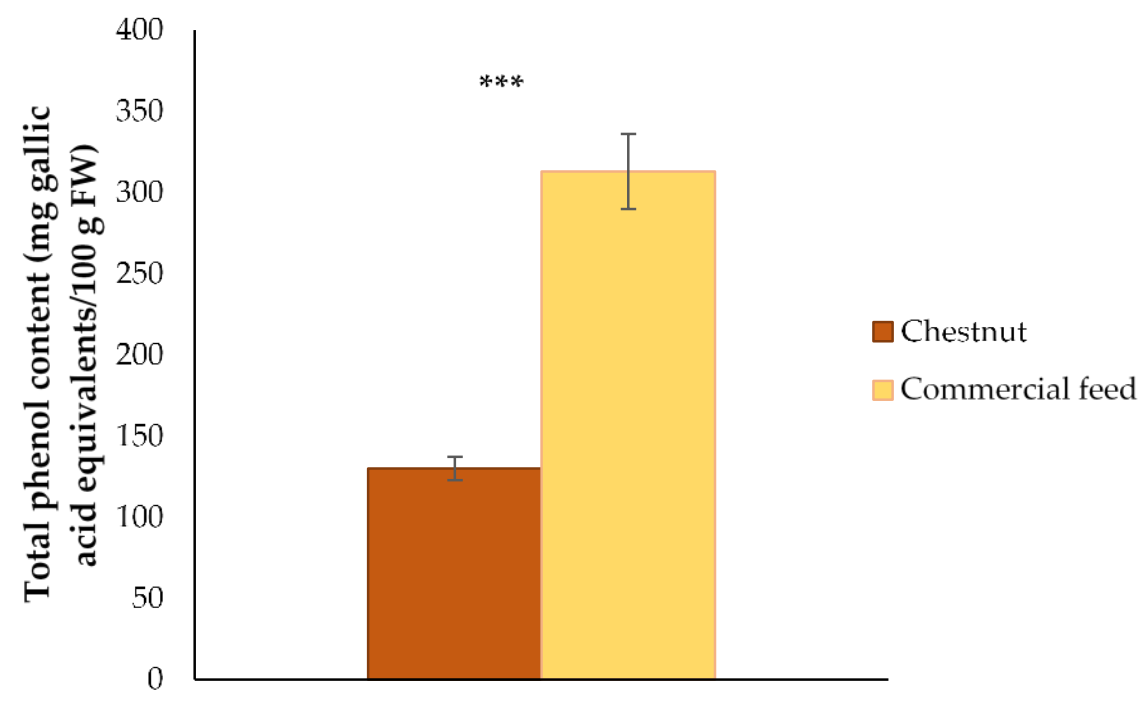

Figure 1. Total phenol content of chestnut and commercial feed used in the finishing diet of Celta pigs (mean \pm standard error of three determinations in each feed). ${ }^{* * *}(P<0.001)$. FW: fresh weight.

The values obtained for the TPC of chestnut (130.00 mg GAE/100 g FW) were similar to those displayed by Hernández Suárez et al. [15], who found mean values of $124 \mathrm{mg}$ GAE/100 g FW for 21 different varieties of chestnut from Tenerife. However, other authors obtained results that were further from ours. For example, Kalogeropoulos et al. [43] and Nazzaro et al. [18] showed lower amounts of TPC for chestnuts from distinct regions. Concretely, Kalogeropoulos et al. [43] observed a TPC of $43.0 \mathrm{mg}$ GAE/100 g FW for chestnuts from a cultivar from Crete Island. For their part, Nazzaro et al. [18] determined a value of $76.3 \mathrm{mg} \mathrm{GAE} / 100 \mathrm{~g}$ FW for "Palomina" cultivar from Italy. In the case of a study conducted by Neri et al. [44], even lower values were observed for three different commercial chestnuts ecotypes from Italy, ranging from 5.1 to $7.9 \mathrm{mg}$ GAE/100 g FW. On the contrary, other works about chestnuts' fruit report a TPC higher than that determined in the present research. This is the case of a work carried out by Özel [45], where values between 137.8-386.4 mg GAE/100 g FW were found in chestnuts belonging to 4 different origins of Turkey. Moreover, Carocho et al. [46] found even higher amounts in chestnuts harvested in the Portugal region, values ranging among 361 and $816 \mathrm{mg}$ GAE/100 g chestnut. Although, it should be noted that samples were previously lyophilized, and the highest amounts of total phenols were shown in chestnuts that were treated prior with different types of radiation. Additionally, Otles and Selek [47] found a TPC between 690-2140 mg GAE/100 g DW in raw chestnuts from three distinct varieties from Turkey. This content is quite high with respect to those found in our study, but it highlights that these authors have expressed the TPC in dry weight, therefore, this difference could be too high. The high variability in TPC reported in literature for chestnuts seems to be a consequence of differences in varieties and geographical origins (edaphic-climatic conditions of cultivation). Additionally, the differences in the procedures used for TP extraction, which involved different solvents, extraction times, temperatures, and auxiliary treatments (e.g., ultrasounds) in some cases, or previous treatments such as irradiation or lyophilisation, could also be partially responsible for these variabilities.

With respect to commercial pig feed, this research has shown that this diet possessed a TPC of $312.89 \mathrm{mg}$ GAE/100 $\mathrm{g}$ FW. These values are higher than those displayed in other studies, where values between 110-116 mg GAE/100 g DW were found for commercial concentrates intended for pig feeding [48,49]. Nevertheless, the higher presence of total polyphenols in commercial feed employed in this research could be due to the existence of certain cereals such as barley and maize. In this way, barley has recently been considered as an ingredient for the production of functional foods [50]. This is so since this cereal possesses high amounts of bioactive substances such as tocopherols, tocotrienols, $\beta$-glucans, 
and different kinds of phenolic compounds like cinnamic and benzoic acid derivatives, proanthocyanidins, quinones, flavonols, chalcones, flavones, flavanones, and amino phenolic compounds [51,52]. More concretely, barley cereal owns higher amounts of phenolic compounds $(0.2-0.4 \%)$ than other cereal grains [53]. For instance, Suriano et al. [54] showed TPC ranging from 192.9 to $291.7 \mathrm{mg} \mathrm{GAE} / 100 \mathrm{~g}$ in whole-grain barley grown in Southern Italy, which are close to the values obtained in this study for the commercial feed (312.89 $\mathrm{mg}$ GAE/100 g FW). For their part, Han et al. [55] displayed a mean value of TPC of $203.314 \mathrm{mg}$ GAE/100 $\mathrm{g}$ for 223 distinct barley genotypes cultivated in southeast China. Additionally, the commercial feed employed in the finishing diet of Celta pig also contained maize among the three main ingredients. This cereal has been found to exhibit a TPC higher than wheat, oat, and rice [51]. Specifically, Lopez-Martinez et al. [56] found a TPC content for four types of corn (white, red, blue, and purple pigmented) ranging from 170.1 to $1760 \mathrm{mg}$ GAE/100 $\mathrm{g}$ of cereal, values among which are the TPC of the commercial feed analyzed in this work. Within these ranges is also the TPC found by Van Hung [51], who evidenced quantities of $264.54 \mathrm{mg}$ GAE/100 g of maize for this parameter. Finally, Saikaew et al. [57] displayed a TPC of $295.98 \mathrm{mg}$ GAE/100 g DW in untreated maize, which was similar to those found in the commercial pig feed supplied in this study.

In addition, even though chestnuts are an important source of phenol compounds [15], this study has determined that commercial feed provides a significantly $(P<0.001)$ higher TPC to the pig diet when comparing this nourishment with chestnuts (312.89 vs. $130.12 \mathrm{mg} \mathrm{GAE} / 100 \mathrm{~g} \mathrm{FW}$ ). This finding disagrees with those described previously by Tejerina et al. [48] and González and Tejeda [49] since these authors observed that the concentrated feed used in the pig diet had a lower content of polyphenols than natural nourishments (namely, grass and acorns) as could be expected in the case of chestnut.

\subsection{Total Flavonoids of Feed Used in the Finishing Diet of Celta Pigs}

Values of total flavonoids of chestnut and commercial feed used in the finishing diet of Celta pigs are displayed in Figure 2 as mg CAE/100 g FW. As we can see, the total flavonoids found in chestnuts' fruit in this research were $8.58 \mathrm{mg}$ CAE/100 $\mathrm{g}$ FW. These outcomes stand out for their low value when compared with those obtained by other authors. For example, Carocho et al. [46] found amounts of total flavonoids between 24 and $234 \mathrm{mg} \mathrm{CAE} / 100 \mathrm{~g}$ lyophilized chestnuts from Portugal. For their part, Antonio et al. [58] displayed values that exceeded $100 \mathrm{mg} \mathrm{CAE} / 100 \mathrm{~g}$ DW also in Portuguese chestnuts, which increased after storage to amounts exceeding $700 \mathrm{mg}$ CAE/100 g DW. Our values also contrast with those displayed by Živković et al. [59], who determined a flavonoid content of $170 \mathrm{mg}$ CAE/100 g DW in chestnuts from Bosnia and Herzegovina. Additionally, Dinis et al. [60] found higher values of these compounds, demonstrating that different ecotypes of this kernel grown in Portugal had a total amount of flavonoids between 480 and $6720 \mathrm{mg}$ CAE /100g DW. As occurred for the TPC, these discordant values could be due to the differences between the distinct varieties, origins, and edaphic-climatic conditions of cultivation of chestnuts compared $[45,47,60]$ and also to the different procedures used for extraction or preliminary treatment.

Regarding commercial feed, this work showed that this diet has total flavonoids of $32.18 \mathrm{mg}$ CAE/100 g FW. The outcomes obtained in this research cannot be compared with other studies, since no bibliography has been found on the matter for commercial compound pig feed. Despite this lack of data, the outcomes obtained for total flavonoids of commercial pig feed have been compared with the presence of these biocompounds in barley and maize, since they are two of the three main feed ingredients. In this way, similar amounts of total flavonoids were obtained for maize (the third ingredient of the feed) by Saikaew et al. [57]. Specifically, they found total flavonoid values between 34.21 and $36.03 \mathrm{mg} \mathrm{CAE} / 100 \mathrm{~g}$ DW for fresh corn. On the other hand, in the case of barley, the values shown for the total flavonoids by Han et al. [55] turned out to be higher than those obtained in the case of the commercial feed supplied in this study $(80.04 \mathrm{vs} .32 .18 \mathrm{mg}$ $\mathrm{CAE} / 100 \mathrm{~g})$. 


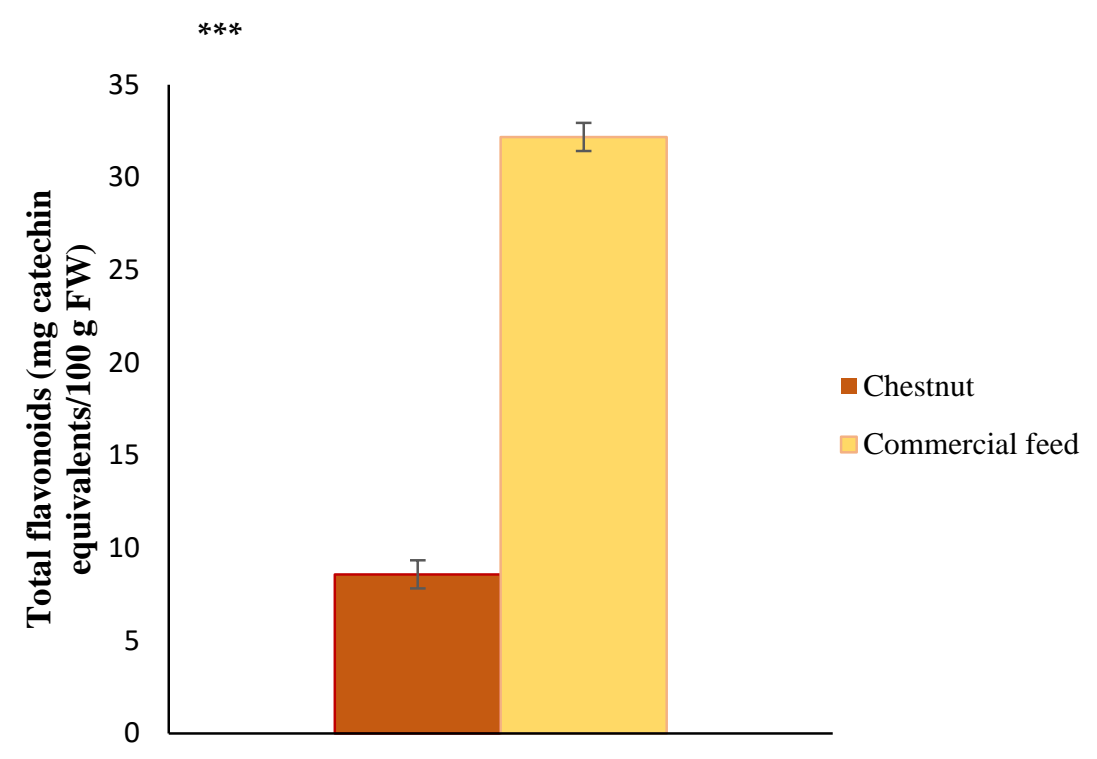

Figure 2. Total flavonoids of chestnut and commercial feed used in the finishing diet of Celta pigs (mean \pm standard error of three determinations in each feed). ${ }^{* * *}(P<0.001)$. FW: fresh weight.

Additionally, it has been observed that the commercial feed showed significantly $(P<0.001)$ higher amounts of total flavonoids than chestnuts analyzed in the present work (32.18 vs. $8.58 \mathrm{mg} \mathrm{CAE} / 100 \mathrm{~g} \mathrm{FW}$ ). Notwithstanding, the values obtained for this swine diet are far from the values showed by other authors for chestnuts, ranging from 100 to $6720 \mathrm{mg} \mathrm{CAE} / 100 \mathrm{~g}$ DW [58-60]. Although, it is true that said values would be within the range of total flavonoids obtained by Carocho et al. [46] for lyophilized chestnuts (24 and $234 \mathrm{mg}$ CAE/100 g).

\subsection{Total Phenol Content of Different Celta Pig Locations}

The presence of compounds with antioxidant properties such as phenols in meat improves the nutraceutical value and the technological quality of meat [20]. Values corresponding to the TPC of the four different locations are presented in Figure 3, expressed as mg GAE/100 g FW. The outcomes obtained for muscle tissue (ranging from 11.70 to $14.06 \mathrm{mg}$ GAE/100 $\mathrm{g}$ FW for chestnut pigs and from 15.08 to $21.43 \mathrm{mg}$ GAE/100 $\mathrm{g}$ FW for commercial feed pigs) were similar to those found by other authors, who showed levels ranging between 12.64 and 24.18 GAE/100 g FW for Iberian pig muscles [48,61]. On the contrary, Simonetti et al. [20] obtained a TPC for the Longissimus lumborum muscle of Italian pigs much higher (between 133.62 and $122.39 \mathrm{mg}$ GAE/100 g FW) than that revealed for the muscles of the present study. However, the values obtained by these authors were very similar to those shown by the liver in both diets in the present work (121.81 mg GAE/100 g FW for liver of pigs fed with chestnut and $140.55 \mathrm{mg}$ GAE/100 $\mathrm{g}$ FW for livers of pigs fed with commercial feed). 


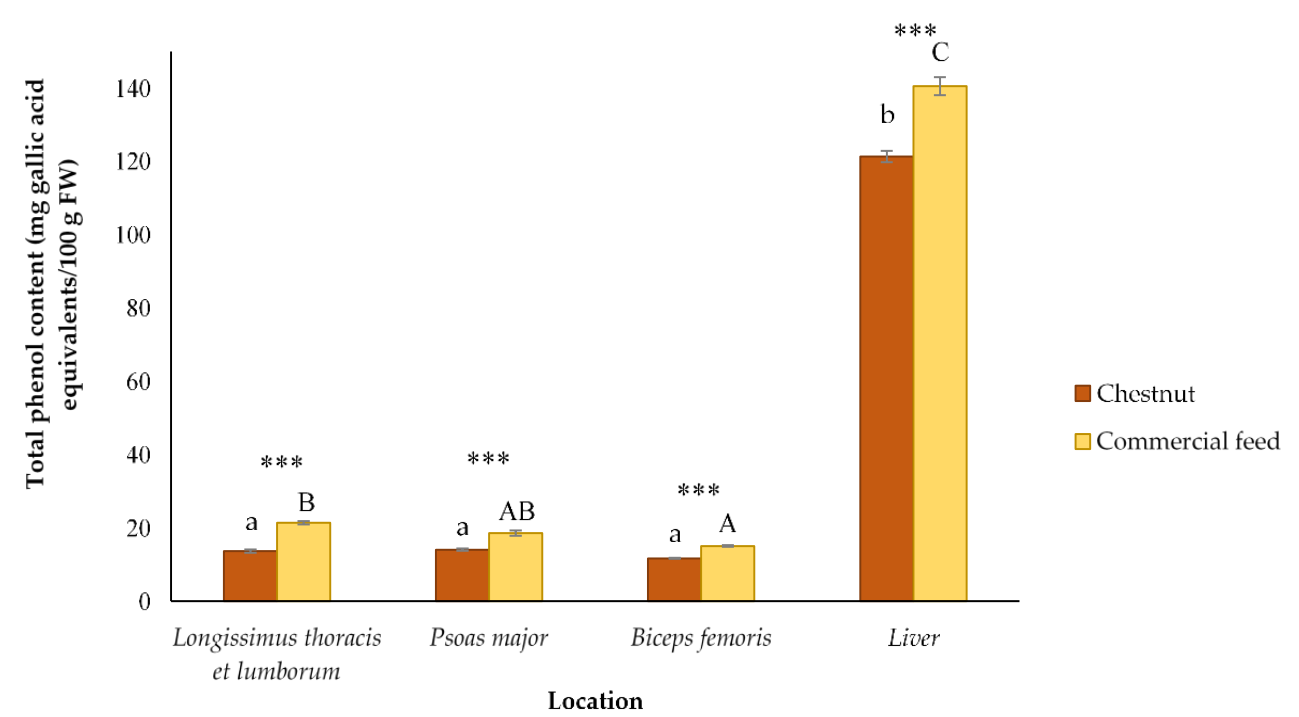

Figure 3. Effect of the inclusion of chestnut in the finishing diet and of location in the carcass on total phenol content of Celta pig tissues (mean \pm standard error of nine carcasses in each feeding group). ${ }^{* *}$ Significant differences $(P<0.001)$ influenced by feeding in each carcass location. ${ }^{\mathrm{a}, \mathrm{b}}$ Means within the same stick for chestnut fed pigs not followed by a common small letter differ significantly $(P<0.05)$ (differences associated to the location). ${ }^{A-C}$ Means within the same stick for commercial feed fed pigs not followed by a common uppercase letter differ significantly $(P<0.05)$ (differences associated to the location). FW: fresh weight.

As can be seen, the inclusion of chestnut fruit in the finishing diet significantly $(P<0.001)$ reduces the values of TPC for all the locations analyzed. This reduction could be related to the lower values of TPC and total flavonoids detected in chestnut compared to the amounts found in commercial feed (Figures 1 and 2), since the presence of phenolic compounds in animal tissues is mainly relegated to the deposition of these substances after the ingestion of plant resources which have said bioactive compounds in their composition [33]. Thereby, the higher content of particular antioxidants in commercial feed could be associated with the greater deposition of these antioxidants in the muscle and liver from pigs fed with this elaborated nourishment, and consequently with a higher TPC (Figure 3). This possible relationship between the amount of phenolic compounds ingested and the phenolic compounds deposited in pig tissues was previously suggested by other authors [61-64]. On this matter, Tejerina et al. [61] observed that a higher TPC in acorn and grass used in the feeding of Iberian pigs provided a significantly higher concentration of these compounds in the Longissimus dorsi and Serratus ventralis muscles. In the same line, González et al. [63] proposed a similar trend in Iberian pigs fed under three different regimes. Concretely, they observed that the highest TPC in the adipose subcutaneous tissue corresponded to pigs raised on acorn and grass, precisely the feeds that had the highest TPC of all the diets tested. Furthermore, Tejerina et al. [48] also found that pigs fattened on a diet richer in polyphenolic compounds (grass and acorn) showed a higher TPC in muscle than pigs fed a concentrate compound that was poorer in these substances. Additionally, Flis et al. [62] proposed that the TPC of pork tissues could be improved by increasing the phenolic content in the supplied diet. Contrary to all these findings, González and Tejeda [49] found that the different content of total phenols in distinct dietary treatments (ranging from 110 to $1694 \mathrm{mg}$ caffeic acid/100 g) did not significantly alter the deposition of phenolic substances in the Longissimus dorsi muscle of Iberian pigs (TPC levels ranging from 16.22 to $19.58 \mathrm{mg}$ caffeic acid/100 g).

However, the relationship between the antioxidant compounds present in the diet and their deposition in the animal's muscle has also been reported in other species such as poultry and rabbits. In this way, Jang et al. [65] observed that supplementation with a dietary medicinal herb extract (rich in polyphenols) at different concentrations ( 0.3 and 
$1.0 \%)$ increased the total polyphenol content of Broiler chicken breasts when compared to a control diet (9.56 and 9.92 vs. 4.88 mg GAE/100 g FW). Furthermore, Perna et al. [64] found that a rabbit diet supplemented with cauliflower leaf powder resulted in a significant increase in TPC in Longissimus lumborum muscle compared to a standard diet (5.98 vs. $4.85 \mathrm{mg} \mathrm{GAE} / 100 \mathrm{~g})$.

On the other hand, the effect of pig location affects TPC in a similar and significant $(P<0.001)$ way in both diets. Thus, lowest TPC was found for Biceps femoris muscle in both diets (11.70 mg GAE/100 g FW for pigs fed with chestnuts, and 15.08 mg GAE/100 g FW for pig fed with commercial feed). Meanwhile, Longissimus thoracis et lumborum and Psoas major muscles showed intermediate values for TPC (13.68 and 14.06 mg GAE/100 g FW in the pigs fed with chestnuts and 21.43 and $18.60 \mathrm{mg} \mathrm{GAE} / 100 \mathrm{~g}$ FW in the pigs fed with commercial feed, respectively). On the contrary, the highest TPC was found for the liver (121.38 and $140.55 \mathrm{mg} \mathrm{GAE} / 100 \mathrm{~g}$ FW for chestnut and commercial feed pigs, respectively). This greater presence of phenolic compounds in liver compared to the muscle tissue could be similar to what occurs with other nutrients, since, for instance, the liver contains important amounts of some vitamins such as retinol (Vitamin A), riboflavin (Vitamin $B_{2}$ ), niacin (Vitamin $\left.B_{3}\right)$, pyridoxine (Vitamin $B_{6}$ ), folacin (Vitamin $B_{9}$ ), cobalamin (Vitamin $B_{12}$ ), ascorbic acid (Vitamin C), and tocopherol (Vitamin E) [66-70].

\subsection{Antioxidant Activity of Feed Used in the Finishing Diet of Celta Pigs}

Various biochemical trials were employed to screen the antioxidant properties: scavenging activity on DPPH and ABTS radicals (considering the decrease in DPPH and ABTS radical absorption after exhibition to radical scavengers) and FRAP assay (the antioxidants present in the samples reduce the ferric ion to its ferrous form of the Fe(III)/tripyridyltriazine complex). Table 2 displays the DDPH and ABTS radical scavenging activity, as $\mu \mathrm{g} \mathrm{TE} / \mathrm{g}$ FW, and FRAP values, as $\mu \mathrm{mol} \mathrm{Fe} \mathrm{Fe}^{2+} / 100 \mathrm{~g} \mathrm{FW}$, of chestnut and commercial feed used in the finishing pig diet.

Table 2. Antioxidant activity of chestnut and commercial feed used in the finishing diet of Celta pigs (mean \pm standard error of three determinations in each feed).

\begin{tabular}{ccccc}
\hline & Chestnut & Commercial Feed & SEM & F \\
\hline \multicolumn{4}{c}{ Antioxidant Activity } & \\
\hline DPPH $(\mu \mathrm{g} \mathrm{TE} / \mathrm{g} \mathrm{FW})$ & $1152.42 \pm 89.84$ & $957.33 \pm 101.50$ & 69.878 & $\mathrm{~ns}$ \\
ABTS $(\mu \mathrm{g} \mathrm{TE} / \mathrm{g} \mathrm{FW}$ & $9379.74 \pm 183.61$ & $7613.44 \pm 139.96$ & 241.704 & $* * *$ \\
FRAP $\left(\mu \mathrm{mol} \mathrm{Fe}^{2+} / 100 \mathrm{~g} \mathrm{FW}\right)$ & $1777.49 \pm 124.72$ & $1946.09 \pm 24.45$ & 64.953 & $\mathrm{~ns}$ \\
\hline
\end{tabular}

FW: fresh weight. TE: Trolox equivalents. SEM: standard error of the mean. F: significance; $* * *(P<0.001)$; ns: no significance.

The antioxidant capacity obtained through DPPH radical scavenging activity and FRAP assay of chestnuts' fruit supplied in this investigation (1152.42 $\mu \mathrm{g}$ TE/g FW and $1777.49 \mu \mathrm{mol} \mathrm{Fe} \mathrm{F}^{2+} / 100 \mathrm{~g}$, respectively) are lower than that obtained in previous studies. In this respect, Abe et al. [71] displayed a DPPH value of $1551.80 \mu \mathrm{g}$ TE/g FW for chestnuts from Central Market of São Paulo (Brazil). For their part, Blomhoff et al. [72] and Carlsen et al. [73] obtained values ranging from 4670 to $4700 \mu \mathrm{mol}$ antioxidant/100 g of chestnut for the FRAP assay. On the contrary, the aftermaths found in this investigation for the ABTS test (9379.74 $\mu \mathrm{g}$ TE/g FW) were much higher than those reported in other works, in which values between 136.66 and $778.4 \mu \mathrm{g}$ TE/g FW were shown [44,74].

With respect to commercial feed, the values found for DPPH, ABTS, and FRAP assays were $957.33 \mu \mathrm{g}$ TE/g FW, $7613.44 \mu \mathrm{g}$ TE/g FW, and $1946.09 \mu \mathrm{mol} \mathrm{Fe}^{2+} / 100 \mathrm{~g}$ FW, respectively. There is little information in literature regarding the antioxidant capacity of feed for pigs. However, a previous study carried out by Smet et al. [75] found values between 12,500 and $68,800 \mu \mathrm{mol} \mathrm{Fe} \mathrm{Fe}^{2+} / 100 \mathrm{~g}$ for the FRAP test in a grain-based feed supplemented with $\alpha$-tocopherol acetate, which were much higher than those shown by the commercial feed supplied in our research. Moreover, the antioxidant activities 
displayed for commercial feed were lower than those found in the main cereals that make up the elaborated nourishment (barley and maize). For example, in the case of DPHH radical scavenging, values between 1419.14 and 16,400.10 $\mu \mathrm{g} \mathrm{TE} / \mathrm{g}$ for barley [62,76] and quantities of $12,314 \mu \mathrm{g} \mathrm{TE} / \mathrm{g}$ for maize [77] were observed. In addition, the ABTS test showed higher values for barley feed (8174.1-12,917.8 $\mu \mathrm{g}$ TE/g) than for the analyzed feed in this research [76]. Contrarily, the commercial feed showed a higher ABTS value than in the case of corn, where values between 1146.3 and $1551.4 \mu \mathrm{g}$ TE/g were found [78].

As can be seen in Table 2 , there are only significant $(P<0.001)$ differences between the diets in the case of the ABTS radical scavenging activity analysis, where the chestnut obtained a higher antioxidant activity than the feed (9379.74 vs. $7613.44 \mu \mathrm{g}$ TE/g FW). Moreover, the DPPH values were also higher for the fruit than for the commercial feed (1152.42 and $957.33 \mu \mathrm{g}$ TE/g FW, respectively), although in this case, the difference was not significant $(P>0.05)$. These events contrast with the values obtained for TPC and total flavonoids for the different feedings (Figures 1 and 2), since both groups of compounds were significantly $(P<0.001)$ higher in commercial feed. However, it is known that the antioxidant power does not depend only on the concentration of antioxidant substances, but also depends on many structural elements such as the number and location of hydroxyl groups linked to the aromatic ring, and the nature and position of the substituent patterns [79]. In this way, it could be affirmed that the polyphenols and flavonoids present in the chestnut, although they are in a lower concentration, have a greater antioxidant efficiency than their counterparts in commercial feed.

Additionally, in contrast to the results obtained for DPPH and ABTS assays, the outcomes found for FRAP method in chestnut fruit were lower than the activities observed in commercial feed (1777.49 and $1946.09 \mu \mathrm{mol} \mathrm{Fe}{ }^{2+} / 100 \mathrm{~g} \mathrm{FW}$, respectively), even though these differences were not significant $(P>0.05)$. This occurrence could suggest the existence of thiol groups in chestnuts, since one disadvantage of FRAP method is the fact that it does not react with thiols [72], unlike the other antioxidant methods used (DPPH and ABTS).

\subsection{Correlation Analysis in Feed Used in the Finishing Diet of Celta Pigs}

In order to clarify the relationship between the TPC and total flavonoids and the antioxidant activities in the diets supplied, a correlation analysis was conducted, and the results were shown in Table 3 . In chestnuts, a positive and significant correlation between TPC and total flavonoids was observed $(r=0.903 ; P<0.01)$, which is consistent with the outcomes reported by Živković et al. [80] for different parts of chestnuts. Additionally, in our study, these two groups of compounds correlated significantly with DPPH radical scavenging activity $(\mathrm{r}=0.794 ; P<0.05$ for TPC; and $\mathrm{r}=0.895 ; P<0.01$; for total flavonoids) and with FRAP values $(\mathrm{r}=0.974 ; P<0.01$ for TPC; and $\mathrm{r}=0.973 ; P<0.01$ for total flavonoids) in the case of chestnuts. Similar aftermaths were obtained by Abe et al. [71] and Dudonné et al. [81], since they observed a high correlation between TPC and antioxidant capacity of different nuts and plants. In this way, it is confirmed that phenols and flavonoids are closely correlated with the antioxidant activity of chestnuts, being the major contributors to the antioxidant properties of this fruit. However, the fact that correlation of TPC with FRAP was higher than with the DPPH could again suggest the additional existence of thiol groups that exert antioxidant activity in chestnut, apart from phenols, which are taken into account in the DPPH assay. In spite of these differences, the DPPH radical scavenging activity and FRAP method showed an acceptable correlation $(\mathrm{r}=0.847 ; P=0.01)$, which indicates that these two assays may be comparable techniques in the evaluation of the antioxidant capacity of chestnuts. On the contrary, the results obtained for ABTS radical scavenging activity are negative and significantly correlated with TPC $(\mathrm{r}=-0.838 ; P<0.01)$ and total flavonoids $(\mathrm{r}=-0.834 ; P<0.01)$ in chestnut feed. These outcomes are inconsistent with the report by Dinis et al. [60], where a positive correlation between both TPC and total flavonoids and the antioxidant activities determined with ABTS was found. Additionally, ABTS values are negative and significantly correlated with DPPH $(\mathrm{r}=-0.832 ; P<0.01)$ and FRAP $(\mathrm{r}=-0.861 ; P<0.01)$ methods. These findings are surprising, since they are in 
disagreement with those obtained in previous studies, where ABTS values were always positively related to the DPPH and FRAP methods [81-83].

Table 3. Pearson correlation coefficients between antioxidant activity, total flavonoids, and total phenol content of chestnuts and commercial feed used in the finishing diet of Celta pigs.

\begin{tabular}{ccccc}
\hline & ABTS & FRAP & TPC & TF \\
\hline DPPH & $-0.832^{* *}$ & Chestnut & $0.895^{* *}$ \\
ABTS & $0.847^{* *}$ & $0.794^{*}$ & $-0.834^{* *}$ \\
FRAP & $-0.861^{* *}$ & $-0.838^{* *}$ & $0.973^{* *}$ \\
TPC & & $0.974^{* *}$ & $0.903^{* *}$ \\
\hline \multicolumn{5}{c}{ Commercial Feed } \\
DPPH & 0.483 & 0.298 & -0.066 \\
ABTS & 0.379 & 0.432 & $0.960^{* *}$ & 0.061 \\
FRAP & & 0.358 & -0.413 \\
TPC & & & 0.092 \\
\hline
\end{tabular}

TF: total flavonoids. TPC: total phenol content. ${ }^{*}(P<0.05) ;{ }^{* *}(P<0.01)$.

On the other hand, in commercial feed, the TPC and total flavonoids are not correlated $(\mathrm{r}=0.092 ; P>0.05)$, which demonstrated that the amount of total flavonoids is not significant in the concentrated diet despite their concentration in this nourishment (Figure 2). Furthermore, these total flavonoids are not responsible for the antioxidant capacity of the commercial feed, since low correlations have been observed with the values obtained for DPPH $(\mathrm{r}=-0.066 ; P>0.05)$, ABTS $(\mathrm{r}=0.061 ; P>0.05)$ and FRAP $(\mathrm{r}=-0.413 ; P>0.05)$. Hence, although the commercial feed has a higher concentration of total flavonoids than chestnuts ( 32.18 vs. $8.58 \mathrm{mg} \mathrm{CAE} / 100 \mathrm{~g} \mathrm{FW}$ ), these compounds are less important than in the natural kernel as they do not show antioxidant activity. Thus, the importance of the structure and integrity of antioxidant compounds is once again highlighted [79]. Regarding TPC, this value has an excellent positive correlation with the ABTS $(r=0.960 ; P<0.01)$ for commercial feed, a fact that differs widely from what happened in chestnuts and that reveals the presence of very different antioxidant compounds in both diets. Additionally, oppositely to ABTS radical scavenging activity, TPC does not have a good correlation with the antioxidant capacity determined by DPPH $(\mathrm{r}=0.298 ; P>0.05)$ and FRAP $(\mathrm{r}=0.358$; $P>0.05$ ) for commercial feed. These low correlations show that TPC does not represent the principal basis for the antioxidant capacity of the compound feed, unlike chestnuts. Therefore, it is expected that the commercial feed contains other types of substances, different than phenols, which are responsible for its antioxidant capacity. Since the commercial feed is artificially supplemented with vitamins, provitamins, and chemically defined substances analogous to Vitamin A, $\mathrm{D}_{3}$, and $\mathrm{E}\left(6500,1500\right.$, and $15 \mathrm{IU} / \mathrm{kg}$ for Vitamin $\mathrm{A}, \mathrm{D}_{3}$, and $\mathrm{E}$, respectively), some of the artificially added compounds could contribute to the antioxidant activity of this nourishment $[68,84,85]$. Finally, the correlation between the three methods used to determine the antioxidant capacity has proven not to be very good in any of the cases for commercial feed $(0.379 \geq \mathrm{r} \leq 0.483 ; P>0.05)$, which indicates that these techniques are not comparable to each other in the analysis of the antioxidant capacity of commercial feed.

\subsection{Antioxidant Activity of Different Celta Pig Locations}

DPPH and ABTS radicals scavenging activity and FRAP assay were used to screen the antioxidant properties of different pig muscles (Longissimus thoracis et lumborum, Psoas major, and Biceps femoris) and liver, in the same way as in the chestnuts and commercial feed diets. Table 4 displayed the effect of diet and location on DDPH and ABTS radical scavenging activity and FRAP values of these pig locations. To our knowledge, limited 
data about the antioxidant activity in pig meat were reported in literature, being difficult to make comparisons.

Table 4. Effect of the inclusion of chestnut in the finishing diet and of location on antioxidant activity of different pig carcass tissues (mean \pm standard error of nine carcasses in each feeding group).

\begin{tabular}{|c|c|c|c|c|c|c|c|}
\hline Location & $\begin{array}{c}\text { Longissimus } \\
\text { thoracis et } \\
\text { Lumborum }\end{array}$ & Psoas major & Biceps femoris & Liver & SEM & $\mathbf{L}$ & LxF \\
\hline \multicolumn{8}{|c|}{ Antioxidant Activity } \\
\hline \multicolumn{8}{|c|}{ DPPH ( $\mu \mathrm{g}$ TE/g FW) } \\
\hline Chestnut pigs & $85.77 \pm 3.27^{\mathrm{a}}$ & $97.55 \pm 2.38^{a}$ & $97.42 \pm 2.02^{a}$ & $669.08 \pm 18.03^{b}$ & 29.927 & $* * *$ & \\
\hline Commercial feed pigs & $124.23 \pm 2.78^{a}$ & $125.76 \pm 2.55^{\mathrm{a}}$ & $131.78 \pm 2.16^{\mathrm{a}}$ & $811.64 \pm 12.91^{b}$ & 35.329 & $* * *$ & $* * * *$ \\
\hline SEM & 3.879 & 2.939 & 3.248 & 16.265 & & & \\
\hline $\mathrm{F}$ & $* * *$ & $* * *$ & $* * *$ & $* * *$ & & & \\
\hline \multicolumn{8}{|c|}{ ABTS ( $\mu$ g TE/g FW) } \\
\hline Chestnut pigs & $503.94 \pm 19.90^{b}$ & $625.83 \pm 19.35^{c}$ & $343.76 \pm 10.37^{a}$ & $1889.67 \pm 58.32^{d}$ & 74.579 & $* * *$ & $* * *$ \\
\hline Commercial feed pigs & $932.10 \pm 30.71^{b}$ & $831.21 \pm 45.42^{b}$ & $395.15 \pm 14.27^{\mathrm{a}}$ & $2047.10 \pm 67.58^{c}$ & 75.456 & $* * *$ & $* * * *$ \\
\hline SEM & 40.430 & 29.889 & 9.717 & 45.960 & & & \\
\hline $\mathrm{F}$ & $* * *$ & $* * *$ & $* *$ & ns & & & \\
\hline \multicolumn{8}{|c|}{ FRAP $\left(\mu \mathrm{mol} \mathrm{Fe}{ }^{2+} / 100 \mathrm{~g} \mathrm{FW}\right)$} \\
\hline Chestnut pigs & $41.58 \pm 1.40^{\mathrm{a}}$ & $53.19 \pm 0.87^{\mathrm{a}}$ & $52.64 \pm 1.32^{a}$ & $659.46 \pm 7.66^{b}$ & 31.429 & $* * *$ & \\
\hline Commercial feed pigs & $54.96 \pm 1.26^{\mathrm{a}}$ & $63.06 \pm 0.98^{a}$ & $59.09 \pm 0.78^{a}$ & $692.52 \pm 13.00^{b}$ & 32.714 & $* * *$ & ns \\
\hline SEM & 1.464 & 1.055 & 0.932 & 7.942 & & & \\
\hline $\mathrm{F}$ & $* * *$ & $* * *$ & $* * *$ & * & & & \\
\hline
\end{tabular}

FW: fresh weight. TE: Trolox equivalents. SEM: standard error of the mean. F: significantly different values as influenced by feeding: ${ }^{*}(P<0.05) ;{ }^{* *}(P<0.01) ; * * *(P<0.001) ;$ ns: no significant difference. L: significantly different values as influenced by location. ${ }^{\text {a-d }}$ Means within the same row not followed by the same letter differ significantly $(P<0.05)$ (influence of location).

Results presented from this research reveal a significant $(P<0.05)$ effect of diet supplied on the antioxidant activity in all pig locations, except for the antioxidant capacity determined by ABTS in the liver. Specifically, the locations from pigs fed commercial feed showed a significantly higher antioxidant activity than that obtained for locations from pigs fed chestnut. These outcomes are in accordance with the muscle and liver contents of phenolic compounds previously reported in both diets (Figure 3), since these substances were found in higher concentration in pigs fed commercial feed. At the same time, these findings are consistent with those obtained for muscles of Iberian pigs, where it was observed that pigs supplemented with feeds that had a higher content of antioxidant compounds showed greater antioxidant capacities [48,61]. In addition, these aftermaths agree with those obtained in a previous study of our research group, where it was observed that the inclusion of chestnut in the finishing diet of Celta pigs increased lipid oxidation of Biceps femoris muscle cooked through different culinary techniques compared with the muscles of pigs fed with commercial feed [86]. This fact could be justified with the findings of the present investigation, meaning it is seen that tissues of pigs fed commercial feed has a higher TPC and higher antioxidant activities. However, despite this agreement, the greater antioxidant capacity found in the locations of pigs fed with commercial feed is in disagreement with the results obtained for the antioxidant activity of both diets, since it was observed that chestnuts had a greater antioxidant capacity than feed when analyzed by the DPPH and ABTS test (Table 2). This incident could be due to the limited absorption that some of the antioxidant compounds present in the chestnut could suffer, since, for example, it has been observed that substances that have thiol groups, which show antioxidant capacity, are absorbed in a limited way [87]. Furthermore, the higher antioxidant activity found in pigs fed commercial feed also contrasts with the results obtained in several investigations on antioxidant status of pigs fed chestnut, because several authors showed 
that the inclusion of chestnut in the finishing diet improved lipid oxidation in different pig matrices [24,26-28]. Simultaneously, our investigation also does not agree with other works that did not show any significant difference in lipid oxidation after using chestnuts in pig fattening $[30,88,89]$.

In relation to the different location, this parameter significantly $(P<0.001)$ affected the antioxidant activities of meat and liver, regardless of the method used. In spite of that, the antioxidant capacities obtained for the muscles analyzed (Longissimus thoracis et lumborum, Psoas major, and Biceps femoris) were very similar to each other, with the greatest difference being found between the muscles and the liver. In this sense, the liver showed antioxidant capacity values much higher than those observed in the muscle tissue in both feedings, which could be due to the liver having interesting amounts of compounds such as vitamins $[66,67]$. Specifically, for the DPPH analysis, the values showed for the muscles were between 85.77-97.55 $\mu \mathrm{g}$ TE/g FW for the pigs fed chestnut and between 124.23$131.78 \mu \mathrm{g}$ TE/g FW for pigs fed commercial feed, with the lowest value corresponding to Longissimus thoracis et lumborum muscle in both diets. Meanwhile, the highest DPPH value was for liver (669.08 and $881.64 \mu \mathrm{g}$ TE/g FW for pigs fed chestnut and commercial feed, respectively). In an identical way, the antioxidant capacity values obtained by the FRAP method showed very similar ranges between the muscles (between 41.58 and $53.19 \mu \mathrm{mol}$ $\mathrm{Fe}^{2+} / 100 \mathrm{~g}$ FW for pigs fed chestnut, and between 54.96 and $63.06 \mu \mathrm{mol} \mathrm{Fe}{ }^{2+} / 100 \mathrm{~g}$ FW for pigs fed commercial feed), again, the Longissimus thoracis et lumborum muscle being the one with the least antioxidant activity of the three muscle tissues. Using the FRAP method, it was also the liver that had the highest antioxidant activity (659.46 and $692.52 \mu \mathrm{g}$ TE/g FW for chestnut and commercial feed liver, respectively). On the other hand, in the case of the ABTS analysis, the values found for the muscle tissues showed greater differences between them. Thus, levels of 343.76, 503.94, and $625.83 \mu \mathrm{g}$ TE/g FW for Biceps femoris, Longissimus thoracis et lumborum, and Psoas major from chestnut pigs were obtained, respectively; and amounts of 395.15, 831.21, and 932.10 $\mu \mathrm{g} \mathrm{TE} / \mathrm{g}$ FW for Biceps femoris, Psoas major, and Longissimus thoracis et lumborum from commercial feed pigs were displayed, respectively. In addition, the highest ABTS values were again for the liver (1889.67 and 2047.10 $\mu \mathrm{g}$ TE/g FW for chestnut and commercial feed liver, respectively).

\subsection{Correlation Analysis of Different Celta Pig Locations}

The Pearson's coefficients between the TPC and the antioxidant activities analyzed by DPPH, ABTS, and FRAP assay of different Celta pig locations were presented in Table 5. The antioxidant activities measured with the three methods were positively correlated with TPC, except for DPPH, ABTS, and FRAP in Biceps femoris muscle from pigs fed commercial feed and DPPH and FRAP in liver from both diets. However, in general, these correlations are not very high, which suggests that there are other substances with antioxidant activity distinct from phenolic compounds in muscle tissues and liver of pigs.

This fact agrees with the premise that the presence of phenols in animal tissues is poor and is relegated to the consumption of vegetal products and their subsequent accumulation [33]. Additionally, the liver stands out for this low correlation in both diets, which may be due to the high presence of other compounds such as vitamins, which also have antioxidant activity $[66,67]$. Notwithstanding, it should be noted that among the three methods used, ABTS is the one that generally presents a greater correlation with the TPC, being significant $(P<0.01)$ in the case of Longissimus thoracis et lumborum and Psoas major muscle from pigs fed both diets and in the case of liver in pigs fed chestnut.

On the other hand, the correlation between the methods is not very high either, which suggests the existence of very different compounds that react differently to the distinct reactants used in the different techniques. This highlights the difficulty in comparing different methods for assessing antioxidant activity in animal tissues. Nevertheless, making a general analysis for all the locations, the existing correlation between the DPPH and the FRAP is the most suitable for making comparisons. 
Table 5. Pearson correlation coefficients between total phenol content and antioxidant activity of different locations of Celta pigs fed chestnut and commercial feed.

\begin{tabular}{|c|c|c|c|}
\hline & ABTS & FRAP & TPC \\
\hline \multicolumn{4}{|c|}{ Chestnut Pigs } \\
\hline \multicolumn{4}{|c|}{ Longissimus thoracis et lumborum } \\
\hline DPPH & $0.488 *$ & 0.401 & 0.222 \\
\hline ABTS & & 0.304 & $0.621^{* *}$ \\
\hline FRAP & & & 0.549 * \\
\hline \multicolumn{4}{|c|}{ Psoas major } \\
\hline DPPH & 0.243 & 0.389 & 0.143 \\
\hline ABTS & & -0.020 & $0.637^{* *}$ \\
\hline FRAP & & & 0.393 \\
\hline \multicolumn{4}{|c|}{ Biceps femoris } \\
\hline DPPH & $0.545^{*}$ & 0.447 & $0.527 *$ \\
\hline ABTS & & 0.045 & 0.413 \\
\hline FRAP & & & 0.303 \\
\hline \multicolumn{4}{|l|}{ Liver } \\
\hline DPPH & -0.171 & $0.535 *$ & -0.336 \\
\hline ABTS & & $-0.470 *$ & $0.628^{* *}$ \\
\hline FRAP & & & -0.351 \\
\hline \multicolumn{4}{|c|}{ Commercial Feed Pigs } \\
\hline \multicolumn{4}{|c|}{ Longissimus thoracis et lumborum } \\
\hline DPPH & -0.045 & 0.164 & 0.008 \\
\hline ABTS & & $0.526^{*}$ & $0.783^{* *}$ \\
\hline FRAP & & & $0.688^{* *}$ \\
\hline \multicolumn{4}{|c|}{ Psoas major } \\
\hline DPPH & 0.354 & $0.495^{*}$ & 0.444 \\
\hline ABTS & & $0.711^{* *}$ & $0.918^{* *}$ \\
\hline FRAP & & & $0.633^{* *}$ \\
\hline \multicolumn{4}{|c|}{ Biceps femoris } \\
\hline DPPH & 0.224 & 0.386 & -0.426 \\
\hline ABTS & & -0.033 & -0.257 \\
\hline FRAP & & & -0.232 \\
\hline Liver & & & \\
\hline DPPH & -0.089 & 0.395 & -0.003 \\
\hline ABTS & & -0.387 & 0.433 \\
\hline FRAP & & & -0.153 \\
\hline
\end{tabular}

TPC: total phenol content. ${ }^{*}(P<0.05) ;{ }^{* *}(P<0.01)$.

\section{Conclusions}

This study has determined that commercial feed provides a higher total phenol content and total flavonoids to the Celta pig's diet when compared to chestnut. However, this fact has not been reflected in the antioxidant capacity assessed in commercial feed, since it has been found that the chestnut had a higher antioxidant capacity when measured by the DPPH and ABTS radical scavenging activity, although only significant differences were displayed through ABTS assay. Furthermore, it has been shown that phenolic compounds, including flavonoids, are the most responsible for the antioxidant capacity of chestnuts. Meanwhile the presence in commercial feed of other chemical compounds, which also exert antioxidant activity, has been revealed. Moreover, the aftermaths of antioxidant capacity obtained for chestnut showed the possible presence of compounds with thiol groups that could display antioxidant activity in this fruit. On the other hand, this research has observed that commercial feed significantly increases the total phenol content, as well as improves the antioxidant activity of different muscles locations (Longissimus thoracis et lumborum, Psoas major, and Biceps femoris) and liver of the Celta pig breed. Simultaneously, it has been demonstrated that in pig tissues, there are also different compounds other than phenols, which have antioxidant capacity. 
In addition, it has been found that the different methods for determining the antioxidant capacity in chestnut showed a better correlation between them than the commercial feed, which could make comparisons between these two diets difficult. At the same time, the existing correlations between DPPH, ABTS, and FRAP in meat were also shown to be low in muscle tissue and liver, highlighting the difficulty of comparing techniques in these animal tissues.

Author Contributions: Conceptualization, J.C. and J.M.L.; formal analysis, N.E.; writing-original draft preparation, N.E. and J.C.; writing—review and editing, P.E.S.M., J.A.C., R.D., M.P., J.C., and J.M.L. All authors have read and agreed to the published version of the manuscript.

Funding: This research received no external funding.

Institutional Review Board Statement: Ethical review and approval were waived for this study, due to the compliance with national and/or European Regulations on animal husbandry (Real Decreto 1221/2009; Real Decreto 1134/2002; European Directive 2008/120EC) and slaughter (Council Directive 93/119/EC).

Informed Consent Statement: Not applicable.

Data Availability Statement: Not applicable.

Acknowledgments: Noemí Echegaray acknowledges to Consellería de Cultura, Educación e Ordenación Universitaria (Xunta de Galicia) for subsiding with a predoctoral scholarship (Grant number IN606A-2018/002). Paulo E. S. Munekata acknowledges postdoctoral fellowship support from the Ministry of Economy and Competitiveness (MINECO, Spain) "Juan de la Cierva" program (FJCI-2016-29486). The authors thank GAIN (Axencia Galega de Innovación) for supporting this investigation (grant number IN607A2019/01). Authors (P.E.S.M., R.D., M.P., and J.M.L) are members of the HealthyMeat network, funded by CYTED (ref. 119RT0568).

Conflicts of Interest: The authors declare no conflict of interest.

\section{References}

1. Moure, A.; Cruz, J.M.; Franco, D.; Domínguez, M.J.; Sineiro, J.; Domínguez, H.; Núñez, M.J.; Parajó, J.C. Natural antioxidants from residual sources. Food Chem. 2001, 72, 145-171. [CrossRef]

2. Rodríguez-Carpena, J.G.; Morcuende, D.; Estévez, M. Avocado by-products as inhibitors of color deterioration and lipid and protein oxidation in raw porcine patties subjected to chilled storage. Meat Sci. 2011, 89, 166-173. [CrossRef]

3. Domínguez, R.; Pateiro, M.; Gagaoua, M.; Barba, F.J.; Zhang, W.; Lorenzo, J.M. A comprehensive review on lipid oxidation in meat and meat products. Antioxidants 2019, 8, 429. [CrossRef]

4. Devatkal, S.K.; Thorat, P.; Manjunatha, M. Effect of vacuum packaging and pomegranate peel extract on quality aspects of ground goat meat and nuggets. J. Food Sci. Technol. 2014, 51, 2685-2691. [CrossRef] [PubMed]

5. Gómez, M.; Lorenzo, J.M. Effect of packaging conditions on shelf-life of fresh foal meat. Meat Sci. 2012, 91, 513-520. [CrossRef] [PubMed]

6. Fernandes, R.P.P.; Trindade, M.A.; Tonin, F.G.; Pugine, S.M.P.; Lima, C.G.; Lorenzo, J.M.; de Melo, M.P. Evaluation of oxidative stability of lamb burger with Origanum vulgare extract. Food Chem. 2017, 233, 101-109. [CrossRef] [PubMed]

7. Zinoviadou, K.G.; Koutsoumanis, K.P.; Biliaderis, C.G. Physico-chemical properties of whey protein isolate films containing oregano oil and their antimicrobial action against spoilage flora of fresh beef. Meat Sci. 2009, 82, 338-345. [CrossRef] [PubMed]

8. Fernandes, R.P.P.; Trindade, M.A.; Lorenzo, J.M.; de Melo, M.P. Assessment of the stability of sheep sausages with the addition of different concentrations of Origanum vulgare extract during storage. Meat Sci. 2018, 137, 244-257. [CrossRef] [PubMed]

9. Lorenzo, J.M.; Pateiro, M.; Domínguez, R.; Barba, F.J.; Putnik, P.; Kovačević, D.B.; Shpigelman, A.; Granato, D.; Franco, D. Berries extracts as natural antioxidants in meat products: A review. Food Res. Int. 2018, 106, 1095-1104. [CrossRef] [PubMed]

10. Granato, D.; Nunes, D.S.; Barba, F.J. An integrated strategy between food chemistry, biology, nutrition, pharmacology, and statistics in the development of functional foods: A proposal. Trends Food Sci. Technol. 2017, 62, 13-22. [CrossRef]

11. Pateiro, M.; Lorenzo, J.M.M.; Amado, I.R.R.; Franco, D. Effect of addition of green tea, chestnut and grape extract on the shelf-life of pig liver pâté. Food Chem. 2014, 147, 386-394. [CrossRef] [PubMed]

12. Lanigan, R.S.; Yamarik, T.A.; Andersen, F.A. Final report on the safety assessment of BHT. J. Am. Coll. Toxicol. 2011, 1, 19-94.

13. Thatoi, H.; Patra, J.K. Biotechnology and pharmacological evaluation of medicinal plants: An overview. J. Herbs Spices Med. Plants 2011, 17, 214-248. [CrossRef]

14. Munekata, P.E.S.; Rocchetti, G.; Pateiro, M.; Lucini, L.; Domínguez, R.; Lorenzo, J.M. Addition of plant extracts to meat and meat products to extend shelf-life and health-promoting attributes: An overview. Curr. Opin. Food Sci. 2020, 31, 81-87. [CrossRef]

15. Hernández Suárez, M.; Rodríguez Galdón, B.; Ríos Mesa, D.; Díaz Romero, C.; Rodríguez Rodríguez, E. Sugars, organic acids and total phenols in varieties of chestnut fruits from Tenerife (Spain). Food Nutr. Sci. 2012, 3, 705-715. 
16. De Vasconcelos, M.d.C.B.M.; Bennett, R.N.; Quideau, S.; Jacquet, R.; Rosa, E.A.S.; Ferreira-Cardoso, J.V. Evaluating the potential of chestnut (Castanea sativa Mill.) fruit pericarp and integument as a source of tocopherols, pigments and polyphenols. Ind. Crops Prod. 2010, 31, 301-311. [CrossRef]

17. Vázquez, G.; Fernández-Agulló, A.; Gómez-Castro, C.; Freire, M.S.; Antorrena, G.; González-Álvarez, J. Response surface optimization of antioxidants extraction from chestnut (Castanea sativa) bur. Ind. Crops Prod. 2012, 35, 126-134. [CrossRef]

18. Nazzaro, M.; Barbarisi, C.; La Cara, F.; Volpe, M.G. Chemical and biochemical characterisation of an IGP ecotype chestnut subjected to different treatments. Food Chem. 2011, 128, 930-936. [CrossRef]

19. Simonetti, A.; Gambacorta, E.; Perna, A. Antioxidative and antihypertensive activities of pig meat before and after cooking and in vitro gastrointestinal digestion: Comparison between Italian autochthonous pig Suino Nero Lucano and a modern crossbred pig. Food Chem. 2016, 212, 590-595. [CrossRef]

20. Simonetti, A.; Perna, A.; Gambacorta, E. Comparison of antioxidant compounds in pig meat from Italian autochthonous pig Suino Nero Lucano and a modern crossbred pig before and after cooking. Food Chem. 2019, 292, 108-112. [CrossRef]

21. Bermúdez, R.; Franco, I.; Franco, D.; Carballo, J.; Lorenzo, J.M. Influence of inclusion of chestnut in the finishing diet on fatty acid profile of dry-cured ham from Celta pig breed. Meat Sci. 2012, 92, 394-399. [CrossRef] [PubMed]

22. Lorenzo, J.M.; Montes, R.; Purriños, L.; Cobas, N.; Franco, D. Fatty acid composition of Celta pig breed as influenced by sex and location of fat in the carcass. J. Sci. Food Agric. 2012, 92, 1311-1317. [CrossRef] [PubMed]

23. Domínguez, R.; Martínez, S.; Gómez, M.; Carballo, J.; Franco, I. Fatty acids, retinol and cholesterol composition in various fatty tissues of Celta pig breed: Effect of the use of chestnuts in the finishing diet. J. Food Compos. Anal. 2015, 37, 104-111. [CrossRef]

24. Pugliese, C.; Sirtori, F.; Acciaioli, A.; Bozzi, R.; Campodoni, G.; Franci, O. Quality of fresh and seasoned fat of Cinta Senese pigs as affected by fattening with chestnut. Meat Sci. 2013, 93, 92-97. [CrossRef] [PubMed]

25. Temperan, S.; Lorenzo, J.M.J.M.; Castiñeiras, B.D.; Franco, I.; Carballo, J.; Castsiñeiras, B.; Franco, I.; Carballo, J. Carcass and meat quality traits of Celta heavy pigs. Effect of the inclusion of chestnuts in the finishing diet. Span. J. Agric. Res. 2014, 12, 694-707. [CrossRef]

26. Díaz, O.; Ros, C.; Veiga, A.; Cobos, Á. Including chestnuts and sugar beet pulp in diets for pigs: The effects on the quality of pork meat and the sensory properties of dry-cured sausage (chorizo gallego). J. Muscle Foods 2009, 20, 449-464. [CrossRef]

27. Cobos, Á.; Veiga, A.; Díaz, O. Influencia de un pienso con castañas y pulpa de remolacha azucarera en la composición lipídica del lacón gallego. Grasas y Aceites 2008, 59, 121-127. [CrossRef]

28. Echegaray, N.; Paterio, M.; Domínguez, R.; Purriños, L.; Bermúdez, R.; Carballo, J.; Lorenzo, J.M. Effects of different cooking methods and of the inclusion of chestnut (Castanea sativa Miller) in the finishing diet of Celta pig breed on the physicochemical parameters and volatile profile of Longissimus thoracis et lumborum muscle. Food Res. Int. 2020, 137, 109407. [CrossRef]

29. Echegaray, N.; Gómez, B.; Barba, F.J.; Franco, D.; Estévez, M.; Carballo, J.; Marszałek, K.; Lorenzo, J.M. Chestnuts and by-products as source of natural antioxidants in meat and meat products: A review. Trends Food Sci. Technol. 2018, 82, 110-121. [CrossRef]

30. Gómez, M.; Fonseca, S.; Cachaldora, A.; Carballo, J.; Franco, I. Effect of chestnuts intake by Celta pigs on lipolytic, oxidative and fatty acid profile changes during ripening and vacuum-packed storage of Galician "chorizo". J. Food Compos. Anal. 2017, 56, 73-83. [CrossRef]

31. Gómez, M.; Cachaldora, A.; Fonseca, S.; Domínguez, R.; Carballo, J.; Franco, I. Biochemical, oxidative, and lipolytic changes during vacuum-packed storage of dry-cured loin: Effect of chestnuts intake by celta pigs. J. Food Qual. 2018, 2018, 7690501. [CrossRef]

32. Kennedy, D.O. Polyphenols and the human brain: Plant "secondary metabolite" ecologic roles and endogenous signaling functions drive benefits. Adv. Nutr. 2014, 5, 515-533. [CrossRef] [PubMed]

33. Estévez, M.; Morcuende, D.; Cava, R. Extensively reared Iberian pigs versus intensively reared white pigs for the manufacture of frankfurters. Meat Sci. 2006, 72, 356-364. [CrossRef] [PubMed]

34. European Union Council Directive 2008/120/EC laying down minimum standards for the protection of pigs. Off. J. Eur. Union 2008, 47, 5-13.

35. Santos, J.; Mendiola, J.A.; Oliveira, M.B.P.P.; Ibáñez, E.; Herrero, M. Sequential determination of fat- and water-soluble vitamins in green leafy vegetables during storage. J. Chromatogr. 2012, 1261, 179-188. [CrossRef]

36. Singleton, V.L.; Rossi, J.A. Colorimetry of total phenolics with phosphomolybdic-phosphotungstic acid reagents. Am. J. Enol. Vitic. 1965, 16, 144-158.

37. Zhishen, J.; Mengcheng, T.; Jianming, W. The determination of flavonoid contents in mulberry and their scavenging effects on superoxide radicals. Food Chem. 1999, 64, 555-559. [CrossRef]

38. Rodrigues, F.; Palmeira-de-Oliveira, A.; das Neves, J.; Sarmento, B.; Amaral, M.H.; Oliveira, M.B. Medicago spp. extracts as promising ingredients for skin care products. Ind. Crops Prod. 2013, 49, 634-644. [CrossRef]

39. Mishra, K.; Ojha, H.; Chaudhury, N.K. Estimation of antiradical properties of antioxidants using DPPH-assay: A critical review and results. Food Chem. 2012, 130, 1036-1043. [CrossRef]

40. Brand-Williams, W.; Cuvelier, M.E.; Berset, C. Use of a free radical method to evaluate antioxidant activity. LWT Food Sci. Technol. 1995, 28, 25-30. [CrossRef]

41. Re, R.; Pellegrini, N.; Proteggente, A.; Pannala, A.; Yang, M.; Rice-Evans, C. Antioxidant activity applying an improved ABTS radical cation decolorization assay. Free Radic. Biol. Med. 1999, 26, 1231-1237. [CrossRef] 
42. Benzie, I.F.F.; Strain, J.J. The ferric reducing ability of plasma (FRAP) as a measure of "antioxidant power": The FRAP assay. Anal. Biochem. 1996, 239, 70-76. [CrossRef] [PubMed]

43. Kalogeropoulos, N.; Chiou, A.; Ioannou, M.S.; Karathanos, V.T. Nutritional evaluation and health promoting activities of nuts and seeds cultivated in Greece. Int. J. Food Sci. Nutr. 2013, 64, 757-767. [CrossRef] [PubMed]

44. Neri, L.; Dimitri, G.; Sacchetti, G. Chemical composition and antioxidant activity of cured chestnuts from three sweet chestnut (Castanea sativa Mill.) ecotypes from Italy. J. Food Compos. Anal. 2010, 23, 23-29. [CrossRef]

45. Özel, H.B. The effects of origin difference on some chemical properties of the fruit of chestnut (Castanea sativa Mill.). Rom. Biotechnol. Lett. 2015, 20, 10969-10975.

46. Carocho, M.; Antonio, A.L.; Barros, L.; Bento, A.; Luisa Botelho, M.; Kaluska, I.; Ferreira, I.C.F.R. Comparative effects of gamma and electron beam irradiation on the antioxidant potential of Portuguese chestnuts (Castanea sativa Mill.). Food Chem. Toxicol. 2012, 50, 3452-3455. [CrossRef]

47. Otles, S.; Selek, I. Effect of processing on the phenolic content and antioxidant activity of chestnuts. Qual. Assur. Saf. Crop. Foods 2012, 4, 3-11. [CrossRef]

48. Tejerina, D.; García-Torres, S.; Cabeza De Vaca, M.; Vázquez, F.M.; Cava, R. Effect of production system on physical-chemical, antioxidant and fatty acids composition of Longissimus dorsi and Serratus ventralis muscles from Iberian pig. Food Chem. 2012, 133, 293-299. [CrossRef]

49. González, E.; Tejeda, J.F. Effects of dietary incorporation of different antioxidant extracts and free-range rearing on fatty acid composition and lipid oxidation of Iberian pig meat. Animal 2007, 1, 1060-1067. [CrossRef]

50. Baik, B.K.; Ullrich, S.E. Barley for food: Characteristics, improvement, and renewed interest. J. Cereal Sci. 2008, 48, $233-242$. [CrossRef]

51. Van Hung, P. Phenolic compounds of cereals and their antioxidant capacity. Crit. Rev. Food Sci. Nutr. 2014, 56, 25-35. [CrossRef] [PubMed]

52. Nordkvist, E.; Salomonssona, A.-C.; Aman, P. Distribution of insoluble bound phenolic acids in barley grain. J. Sci. Food Agric. 1984, 35, 657-661. [CrossRef]

53. Bendelow, V.M.; LaBerge, D.E. Relationships among barley, malt, and beer phenolics. J. Am. Soc. Brew. Chem. 1979, 37, 89-90. [CrossRef]

54. Suriano, S.; Iannucci, A.; Codianni, P.; Fares, C.; Russo, M.; Pecchioni, N.; Marciello, U.; Savino, M. Phenolic acids profile, nutritional and phytochemical compounds, antioxidant properties in colored barley grown in southern Italy. Food Res. Int. 2018, 113, 221-233. [CrossRef]

55. Han, Z.; Zhang, J.; Cai, S.; Chen, X.; Quan, X.; Zhang, G. Association mapping for total polyphenol content, total flavonoid content and antioxidant activity in barley. BMC Genom. 2018, 19, 1-10. [CrossRef]

56. Lopez-Martinez, L.X.; Parkin, K.L.; Garcia, H.S. Phase II-Inducing, polyphenols content and antioxidant capacity of corn (Zea mays L.) from phenotypes of white, blue, red and purple colors processed into masa and tortillas. Plant Foods Hum. Nutr. 2011, 66, 41-47. [CrossRef]

57. Saikaew, K.; Lertrat, K.; Meenune, M.; Tangwongchai, R. Effect of high-pressure processing on colour, phytochemical contents and antioxidant activities of purple waxy corn (Zea mays L. var. ceratina) kernels. Food Chem. 2017, 243, 328-337. [CrossRef]

58. Antonio, A.L.; Fernandes, Â.; Barreira, J.C.M.; Bento, A.; Botelho, M.L.; Ferreira, I.C.F.R. Influence of gamma irradiation in the antioxidant potential of chestnuts (Castanea sativa Mill.) fruits and skins. Food Chem. Toxicol. 2011, 49, 1918-1923. [CrossRef]

59. Živković, J.; Zeković, Z.; Mujić, I.; Tumbas, V.; Cvetković, D.; Spasojević, I. Antioxidant properties of phenolics in Castanea sativa Mill. extracts. Food Technol. Biotechnol. 2009, 47, 421-427.

60. Dinis, L.T.; Oliveira, M.M.; Almeida, J.; Costa, R.; Gomes-Laranjo, J.; Peixoto, F. Antioxidant activities of chestnut nut of Castanea sativa Mill. (cultivar "Judia") as function of origin ecosystem. Food Chem. 2012, 132, 1-8. [CrossRef]

61. Tejerina, D.; García-Torres, S.; Cabeza de Vaca, M.; Vázquez, F.M.; Cava, R. Study of variability in antioxidant composition and fatty acids profile of Longissimus dorsi and Serratus ventralis muscles from Iberian pigs reared in two different Montanera seasons. Meat Sci. 2012, 90, 414-419. [CrossRef] [PubMed]

62. Flis, M.; Sobotka, W.; Antoszkiewicz, Z.; Lipiński, K.; Zduńczyk, Z. The effect of grain polyphenols and the addition of vitamin E to diets enriched with $\alpha$-linolenic acid on the antioxidant status of pigs. J. Anim. Feed Sci. 2010, 19, 539-553. [CrossRef]

63. González, E.; Tejeda, J.F.; Motilva, M.J.; Romero, M.P. Phenolic compounds in subcutaneous adipose tissue from Iberian pigs. Options Méditerranéennes Ser. A 2003, 118, 115-118.

64. Perna, A.; Simonetti, A.; Grassi, G.; Gambacorta, E. Effect of a cauliflower (Brassica oleraceae var. Botrytis) leaf powder-enriched diet on performance, carcass and meat characteristics of growing rabbit. Meat Sci. 2018, 149, 134-140.

65. Jang, A.; Liu, X.D.; Shin, M.H.; Lee, B.D.; Lee, S.K.; Lee, J.H.; Jo, C. Antioxidative potential of raw breast meat from broiler chicks fed a dietary medicinal herb extract mix. Poult. Sci. 2008, 87, 2382-2389. [CrossRef]

66. Yu, H.C.; Hsu, J.-L.L.; Chang, C.-I.I.; Tan, F.-J.J. Antioxidant properties of porcine liver proteins hydrolyzed using Monascus purpureus. Food Sci. Biotechnol. 2017, 26, 1217-1225. [CrossRef]

67. Kakimov, A.; Suychinov, A.; Tsoy, A.; Mustambayev, N.; Ibragimov, N.; Kuderinova, N.; Mirasheva, G.; Yessimbekov, Z. Nutritive and biological value of liver and blood of various slaughtered animals. J. Pharm. Res. Int. 2018, 22, 1-5. [CrossRef]

68. Rey, A.I.; López-Bote, C.J.; Litta, G. Effects of dietary vitamin E (DL- $\alpha$-tocopheryl acetate) and vitamin C combination on piglets oxidative status and immune response at weaning. J. Anim. Feed Sci. 2017, 26, 226-235. [CrossRef] 
69. Amazan, D.; Cordero, G.; López-Bote, C.J.; Lauridsen, C.; Rey, A.I. Effects of oral micellized natural vitamin E (d- $\alpha$-tocopherol) v. synthetic vitamin $\mathrm{E}$ (dl- $\alpha$-tocopherol) in feed on $\alpha$-tocopherol levels, stereoisomer distribution, oxidative stress and the immune response in piglets. Animal 2014, 8, 410-419. [CrossRef]

70. Rey, A.I.; Lopez-Bote, C.J.; Kerry, J.P.; Lynch, P.B.; Buckley, D.J.; Morrissey, P.A. Modification of lipid composition and oxidation in porcine muscle and muscle microsomes as affected by dietary supplementation of n-3 with either n-9 or n-6 fatty acids and $\alpha$-tocopheryl acetate. Anim. Feed Sci. Technol. 2004, 113, 223-238. [CrossRef]

71. Abe, L.T.; Lajolo, F.M.; Genovese, M.I. Comparison of phenol content and antioxidant capacity of nuts. Ciencia e Tecnol. Alimentar 2010, 30, 254-259. [CrossRef]

72. Blomhoff, R.; Carlsen, M.H.; Andersen, L.F.; Jacobs, D.R. Health benefits of nuts: Potential role of antioxidants. Br. J. Nutr. 2006, 96, 52-60. [CrossRef] [PubMed]

73. Carlsen, M.H.; Halvorsen, B.L.; Holte, K.; Bøhn, S.K.; Dragland, S.; Sampson, L.; Willey, C.; Senoo, H.; Umezono, Y.; Sanada, C.; et al. The total antioxidant content of more than 3100 foods, beverages, spices, herbs and supplements used worldwide. Nutr. J. 2010, 9, 9-11. [CrossRef] [PubMed]

74. Barros, A.I.R.N.A.; Nunes, F.M.; Gonalves, B.; Bennett, R.N.; Silva, A.P. Effect of cooking on total vitamin C contents and antioxidant activity of sweet chestnuts (Castanea sativa Mill.). Food Chem. 2011, 128, 165-172. [CrossRef]

75. Smet, K.; Raes, K.; de Smet, S. Novel approaches in measuring the antioxidative potential of animal feeds: The FRAP and DPPH methods. J. Sci. Food Agric. 2006, 86, 2412-2416. [CrossRef]

76. Yang, X.J.; Dang, B.; Fan, M.T. Free and bound phenolic compound content and antioxidant activity of different cultivated blue highland barley varieties from the qinghai-tibet plateau. Molecules 2018, 23, 879. [CrossRef]

77. Herrera-Sotero, M.Y.; Cruz-Hernández, C.D.; Trujillo-Carretero, C.; Rodríguez-Dorantes, M.; García-Galindo, H.S.; Chávez-Servia, J.L.; Oliart-Ros, R.M.; Guzmán-Gerónimo, R.I. Antioxidant and antiproliferative activity of blue corn and tortilla from native maize. Chem. Cent. J. 2017, 11, 1-8. [CrossRef]

78. Hernández, M.; Ventura, J.; Castro, C.; Boone, V.; Rojas, R.; Ascacio-Valdés, J.; Martínez-Ávila, G. UPLC-ESI-QTOF-MS2-based identification and antioxidant activity assessment of phenolic compounds from red corn Cob (Zea mays L.). Molecules 2018, 23, 1425. [CrossRef]

79. Sroka, Z.; Cisowski, W. Hydrogen peroxide scavenging, antioxidant and anti-radical activity of some phenolic acids. Food Chem. Toxicol. 2003, 41, 753-758. [CrossRef]

80. Živković, J.; Zeković, Z.; Mujić, I.; Vidović, S.; Cvetković, D.; LepoJević, Ž.; Nikolić, G.; Trutić, N. Scavenging capacity of superoxide radical and screening of antimicrobial activity of Castanea sativa Mill. extracts. Czech J. Food Sci. 2010, 28, 61-68. [CrossRef]

81. Dudonné, S.; Vitrac, X.; Coutiére, P.; Woillez, M.; Mérillon, J.M. Comparative study of antioxidant properties and total phenolic content of 30 plant extracts of industrial interest using DPPH, ABTS, FRAP, SOD, and ORAC assays. J. Agric. Food Chem. 2009, 57, 1768-1774. [CrossRef] [PubMed]

82. Thaipong, K.; Boonprakob, U.; Crosby, K.; Cisneros-Zevallos, L.; Hawkins Byrne, D. Comparison of ABTS, DPPH, FRAP, and ORAC assays for estimating antioxidant activity from guava fruit extracts. J. Food Compos. Anal. 2006, 19, 669-675. [CrossRef]

83. Todorovic, V.; Milenkovic, M.; Vidovic, B.; Todorovic, Z.; Sobajic, S. Correlation between antimicrobial, antioxidant activity, and polyphenols of alkalized/nonalkalized cocoa powders. J. Food Sci. 2017, 82, 1020-1027. [CrossRef] [PubMed]

84. Olivares, A.; Rey, A.I.; Daza, A.; Lopez-Bote, C.J. High dietary vitamin A interferes with tissue -tocopherol concentrations in fattening pigs: A study that examines administration and withdrawal times. Animal 2009, 3, 1264-1270. [CrossRef]

85. Rey, A.I.; Segura, J.F.; Castejón, D.; Fernández-Valle, E.; Cambero, M.I.; Calvo, L. Vitamin D3 supplementation in drinking water prior to slaughter improves oxidative status, physiological stress, and quality of pork. Antioxidants 2020, 9, 559. [CrossRef]

86. Echegaray, N.; Pateiro, M.; Zhang, W.; Domínguez, R.; Campagnol, P.C.B.; Carballo, J.; Lorenzo, J.M. Influence of the Inclusion of chestnut (Castanea sativa Miller) in the finishing diet and cooking technique on the physicochemical parameters and volatile profile of biceps femoris muscle. Foods 2020, 9, 754. [CrossRef]

87. Buettner, G.R. The pecking order of free radicals and antioxidants: Lipid peroxidation, $\alpha$-tocopherol, and ascorbate. Arch. Biochem. Biophys. 1993, 300, 535-543. [CrossRef]

88. Prevolnik, M.; Škrlep, M.; Brus, M.; Pugliese, C.; Čandek-Potokar, M.; Škorjanc, D. Supplementing pig diet with 0.2\% sweet chestnut (Castanea sativa Mill.) wood extract had no effect on growth, carcass or meat quality. Acta Agric. Slov. 2012, $100,83-88$.

89. Echegaray, N.; Domínguez, R.; Franco, D.; Lorenzo, J.M.; Carballo, J. Effect of the use of chestnuts (Castanea sativa Miller) in the finishing diet of Celta pig breed on the shelf-life of meat refrigerated and frozen. Food Res. Int. 2018, 114, 114-122. [CrossRef] 